\title{
RRAS2 Gene
}

National Cancer Institute

\section{Source}

National Cancer Institute. RRAS2 Gene. NCI Thesaurus. Code C24755.

This gene is involved in signal transduction and intracellular protein transport. 